\title{
Effect of Harpin protein as an elicitor on the content of phenolic compounds and antioxidant capacity in two hydroponically grown lettuce (Lactuca sativa L.) varieties.
}

\author{
Joaquín RODRIGO-GARCÍA ${ }^{1 *}$, Benjamín Alejandro NAVARRETE-LABORDE², Laura Alejandra de la ROSA³, \\ Emilio ALVAREZ-PARRILLA³, José Alberto NÚÑEZ-GASTÉLUM ${ }^{3}$
}

\begin{abstract}
Harpin protein was used as an elicitor in green (butterhead) and red (oak leaf type) varieties of hydroponically grown lettuce (Lactuca sativa L.). Its impact on polyphenolic content and antioxidant capacity was evaluated. Harpin protein was sprayed three days before harvesting in concentrations of 45, 60, and $120 \mathrm{mg} / \mathrm{L}$. Green lettuce samples showed a positive response to Harpin by significantly increasing its phenolic content from 12 (control) to $16.43 \mathrm{mg}$ gallic acid equivalents (GAE)/100 g dry weight (DW) (120 mg/L Harpin treatment) which means a 36.9\% increase. Chlorogenic acid was the only phenolic compound that increased its concentration after lettuce induction with Harpin treatment. Antioxidant capacity, evaluated by 2,2-diphenyl-1-picrylhydrazyl $\left(\mathrm{DPPH}^{\circ}\right)$ and ferric reducing antioxidant power (FRAP) methods, also showed a significant increase (46.5 and $64.3 \%$, respectively) in Harpin-treated green lettuce. The red lettuce variety showed none or a negative response to Harpin treatment for all parameters evaluated. These results show that elicitation may be an effective strategy to enhance phenolic content in lettuce varieties.
\end{abstract}

Keywords: lettuce; polyphenols; antioxidant capacity; Harpin protein; elicitor.

Practical Application: Enhance of polyphenols and antioxidant capacity in lettuce produced under hydroponic system using Harpin protein.

\section{Introduction}

Lettuce (Lactuca sativa $L$ ) is one of the most popular leafy vegetables and it is consumed most of the time as an ingredient in fresh salads. This vegetable is a good source of antioxidant phytochemicals such as phenolic compounds, which in turn are reputed to decrease the risk of suffering such diseases as cardiovascular disease, cancer, and age related degenerative processes (Viacava et al., 2014). Phytochemicals in lettuce are mainly secondary metabolites synthesized either during normal growth or under different stress sources (Boo et al., 2011). As a result, there is a growing interest in their beneficial properties and in how to increase the contents of these bioactive compounds in vegetables to improve the nutritional composition of plant foods (Martínez-Ballesta et al., 2008). Growing conditions that trigger plant defense mechanisms against different types of stress have been used as methods to increase the content of antioxidants in plants (Oh et al., 2009).

Three main ways to enhance the quality of fresh vegetables are possible: genetic modifications, agronomical management, and elicitation. However, since genetically modified food still has a long way to go regarding public acceptance, elicitation appears to be a sensible approach to improve health-promoting phytochemicals (Złotek et al., 2014).

Harpin protein, originally isolated from Erwinia amylovora, is one of the plant activators that have become common in biological agriculture practices. When applied, Harpin protein binds to plant receptors that activate several biochemical pathways related to growth and resistance enhancement by way of a systemic acquired resistance pathway (SAR) (Akbudak et al., 2006). It is reported that an improved accumulation of phenolics may be one of the mechanisms that help control pathogen growth (Fonseca et al., 2009).

Harpin has been reported to stimulate the activity of phenylalanine ammonia lyase enzyme, a key to the biosynthesis of polyphenolic compounds such as gallic, caffeic, chlorogenic and some other acids (Boo et al., 2011). In the present study, we assessed the ability of Harpin protein to induce accumulation of phenolic compounds with antioxidant activity in the leaves of green and red lettuce.

\section{Material and methods}

\subsection{Chemicals}

All substances were purchased from Sigma (St. Louis, MO, USA). Solvents were acquired from JT Baker (Phillipsburg, NJ, USA). All chemical were reactive grade with the exception of methanol and acetonitrile, which were HPLC grade for they were used as mobile phase. 


\subsection{Growth conditions}

Green butterhead (Lactuca sativa var capitata) and red oak leaf (Lactuca sativa var crispa) were used in this research. All lettuce samples were grown at the InnoBio facility (Ciudad Juarez, Chihuahua, Mexico) in a recirculating hydroponics system (InnoGarden H-50 from InnoBio) with a photoperiod of $16 \mathrm{~h} /$ day; a light intensity of $600 \mu \mathrm{mol} / \mathrm{m}^{2} \mathrm{~s}$; relative humidity of 40-60\%; and an environmental temperature of $20-25^{\circ} \mathrm{C}$. Growth conditions were pesticide-free, i.e., no chemical substances such as pesticides, fungicides, or herbicides were used. Seeds were certified to be organic and Non-GMO (Genetically Modified Organism). The samples were organized into four groups composed of three green and three red lettuces each one. According to previously published studies carried out with Harpin protein (Fonseca et al., 2009) with some modifications, the elicitor was applied as follows: 45 (H45), 60 (H60), and 120 (H120) mg/L of Harpin protein (Messenger, Plant Health Care de Mexico, D.F.) dissolved in ultrapure water by reverse osmosis (RO). The elicitor was sprayed three times (approximately $1.5 \mathrm{~mL}$ ) directly onto the leaves three days prior to harvest, as reported by Zloteck et al, 2014. A control group was sprayed three times with ultrapure $\mathrm{RO}$ water.

\subsection{Preparation of samples}

Samples were collected on harvest day, i.e. 3 three days after being treated with Harpin. Once collected, they were refrigerated and transported to the laboratory where they were kept at $-80^{\circ} \mathrm{C}$ until further analysis. All roots were removed and the remaining parts (leaves) weighted. Samples of approximately $100 \mathrm{~g}$ were freeze-dried (Labconco freeze dry/shell freeze system, Labconco Corporation, Kansas City, MO, USA) for 4 days and kept at $-80{ }^{\circ} \mathrm{C}$ until phytochemical analysis.

\subsection{Total phenolic content}

Phenolic compounds were extracted with $80 \%$ methanol according to the protocol described in Alvarez-Parrilla et al. (2010): $0.1 \mathrm{~g}$ of freeze-dried sample was weighed into screw-cap tubes. After adding $4 \mathrm{~mL}$ of solvent, the sample was sonicated for $30 \mathrm{~min}$ and centrifuged at 4,000 rpm for $20 \mathrm{~min}$. This process was performed twice. The resulting extracts were placed in $10 \mathrm{~mL}$ volumetric flasks. $250 \mu \mathrm{L}$ of this extract were then taken, mixed with $1,000 \mu \mathrm{L}$ of $\mathrm{Na}_{2} \mathrm{CO}_{3}(7.5 \%)$, and left sitting for $2 \mathrm{~min} .1,250 \mu \mathrm{L}$ of Folin-Ciocalteu reagent were then added and incubated at $50{ }^{\circ} \mathrm{C}$ for $15 \mathrm{~min}$. Finally, the mixture was cooled in an ice bath so that $300 \mu \mathrm{L}$ would be collected and placed in a microplate well to measure absorbance at $760 \mathrm{~nm}$ in a BioRad xMark Plus. Data were retrieved by means of the Microplate Manager 6.0 (BioRad, Tokyo, Japan) computer software. A calibration curve was performed using gallic acid as a standard and the results were expressed in mg GAE/g dry weight (DW).

\subsection{Determination of the Phenolic profile}

Individual phenolic compounds were quantified by HPLC following the protocol in De La Rosa et al. (2011) with minor modifications. Phenolic compounds were extracted as described in the previous section. One $\mathrm{mL}$ of the extract was filtered through a $0.45 \mu \mathrm{m}$ membrane, and $20 \mu \mathrm{L}$ were injected into the HPLC system. The equipment used included a Perkin Elmer Series 200 chromatograph with a quaternary pump, column oven, and diode array detector (Shelton, CT, USA). A C18 Phenomenex column ( $5 \mu \mathrm{m}, 250 \mathrm{x} 46 \mathrm{~mm}$, Torrance, CA, USA) was used, the absorbance was monitored at 280 and $320 \mathrm{~nm}$, and characteristic absorption spectra were collected. The binary mobile phase employed methanol:acetronile as Solvent A (95:5); and $1 \%$ phosphoric acid in water as solvent $\mathrm{B}$. The gradient program was: $2.5 \mathrm{~min}, 100 \% \mathrm{~B} ; 5.5 \mathrm{~min}, 70 \% \mathrm{~B} ; 22.5 \mathrm{~min}, 20 \%$ $\mathrm{B}$; and $25.5 \mathrm{~min}, 100 \% \mathrm{~B}$.

\subsection{Determination of the Antioxidant capacity}

Antioxidant activity was analyzed by FRAP, DPPH assay and TROLOX equivalent antioxidant activity (TEAC) (Alvarez-Parrilla et al., 2011). To determine FRAP, a standard curve was performed using TROLOX, which forms a colored complex with 2,4,6-tripyridyl-s-triazine (TPTZ). All solutions were prepared in $80 \%$ methanol in water. One hundred $\mu \mathrm{L}$ of the extract were mixed with $300 \mu \mathrm{L}$ of water, vortexed, and $24 \mu \mathrm{L}$ of the mixture were placed in a microplate well with $180 \mu \mathrm{L}$ of TPTZ working solution (a mixture of $0.3 \mathrm{M}$ acetate buffer, $\mathrm{pH}$ 3.6; $10 \mathrm{mM}$ TPTZ solution in $40 \mathrm{mM} \mathrm{HCl}$ and $20 \mathrm{mM} \mathrm{FeCl}_{3}$, at a 10:1:1 ratio). Absorbance was read at $595 \mathrm{~nm}$ every 30 seconds for $30 \mathrm{~min}$. Results were expressed as $\mu \mathrm{mol}$ TROLOX equivalents (TE)/g DW. For the DPPH assay, a $190 \mathrm{mM} \mathrm{DPPH}$ solution was prepared in methanol; $25 \mu \mathrm{L}$ of the extract were added to $200 \mu \mathrm{L}$ of the DPPH solution and the absorbance read at $517 \mathrm{~nm}$ every 30 seconds for $30 \mathrm{~min}$.

The $\mathrm{ABTS}^{\bullet+}$ radical on the TEAC assay was generated by mixing ABTS $(7 \mathrm{mM})$ and potassium persulphate $(2.45 \mathrm{mM})$ in distilled water and left to react for $16 \mathrm{~h}$. A suitable volume of this solution was diluted in ethanol to yield an absorbance of about 0.7 at $734 \mathrm{~nm}$. Subsequently, $285 \mu \mathrm{L}$ of the $\mathrm{ABTS}^{\cdot+}$ radical were mixed with $12 \mu \mathrm{L}$ of the sample (or calibration standard) and absorbance was measured every 30 seconds for 6 min at $734 \mathrm{~nm}$.

\section{Results and discussions}

\subsection{Effect of Harpin on total phenolic content}

Table 1 shows that Harping treatment affected only the green lettuce variety, while no effect was observed on red lettuce. The green lettuce variety showed a dose dependent increase of phenolic compounds with increasing Harpin doses. Phenolic

Table 1. Total phenolic compounds (mg GAE/g DW) for the control group and different Harpin concentration treatments in green and red varieties of lettuce.

\begin{tabular}{|c|c|c|c|c|}
\hline Treatment & Green variety & $\begin{array}{l}\text { \% Dry } \\
\text { matter }\end{array}$ & Red variety & $\begin{array}{l}\text { \% Dry } \\
\text { matter }\end{array}$ \\
\hline Control & $12.00 \pm 1.16^{\mathrm{a}}$ & $5.5^{\mathrm{a}}$ & $30.61 \pm 3.83^{\mathrm{a}}$ & $6.5^{\mathrm{a}}$ \\
\hline Harpin $45 \mathrm{mg} / \mathrm{L}$ & $13.29 \pm 0.27^{\mathrm{ab}}$ & $4.7^{\mathrm{a}}$ & $24.87 \pm 1.68^{\mathrm{a}}$ & $5.8^{\mathrm{a}}$ \\
\hline Harpin $60 \mathrm{mg} / \mathrm{L}$ & $14.96 \pm 1.55^{\mathrm{bc}}$ & $5.1^{\mathrm{a}}$ & $26.47 \pm 1.48^{\mathrm{a}}$ & $5.6^{\mathrm{a}}$ \\
\hline Harpin 120 mg/L & $16.43 \pm 0.56^{c}$ & $6.8^{\mathrm{b}}$ & $26.92 \pm 3.73^{\mathrm{a}}$ & $5.6^{\mathrm{a}}$ \\
\hline
\end{tabular}


content ranged from $12.00 \pm 1.16 \mathrm{mg} \mathrm{GAE} / \mathrm{g}$ DW in the control group to $16.43 \pm 0.56 \mathrm{mg} \mathrm{GAE} / \mathrm{g} \mathrm{DW}$ in the $120 \mathrm{mg} / \mathrm{L}$ of Harpin protein group. Significant differences were observed between the control and the groups treated with Harpin protein at concentrations of 60 and $120 \mathrm{mg} / \mathrm{L}$. These two concentration values showed increases of 24.6 and $36.9 \%$ in their phenolic content, respectively. This data agrees with those reported by Fonseca et al. (2009) where a 25\% increase of phenolic compounds was found in the inner leaves when treated 1 day before harvest with 60 and $90 \mathrm{mg} / \mathrm{L}$ of Harpin protein, compared to control. When Harpin application was done at lower concentrations or at 7 days before harvest, no differences were found with respect to control group. For outer leaves, all treatments $(30,60,90 \mathrm{mg} / \mathrm{L})$ generated a phenolic increase when applied 7 days before harvest and only the two highest triggered an increment in phenolic levels when applied 1 day before. However, data from the outer leaves in their research shows that the same treatment triggered an increase of phenolic compounds of only 7-9\%. Despite Harpin effect, Fonseca et al. (2009) found three times more phenolics in the outer leaves than in the inner leaves. Regardless of our data showing a more powerful response, the phenolic content in our samples was significantly lower compared with those reported by Fonseca et al. (2009). As we used the whole lettuce to make a pool and analyze phenolic compounds and antioxidant capacity, we decided to choose an intermediate day for Harpin application and it was set 3 days before harvest point

Phenolic content in green lettuce samples treated with Harpin $120 \mathrm{mg} / \mathrm{L}$ was higher than that reported for Butterhead (15.1 mg/g DW) and Iceberg lettuce (10.4 mg/g DW) (Liu et al., 2007). Low phenolic levels were also reported for Romaine, mini Romaine and Little Gem lettuce (López et al., 2014) both for inner and outer leaves of Butterhead lettuce (Viacava et al., 2014).

Other studies have use different treatments to increase phenolic compounds in lettuce. Boo et al. (2011) used different photoperiod and temperatures, finding that the coldest conditions $\left(13 \mathrm{~h}\right.$ at $10^{\circ} \mathrm{C}$ and $20 \mathrm{~h}$ at $13^{\circ} \mathrm{C}$ ) triggered phenolic compounds in concentrations higher than those found in our assay with Harpin protein. In another study, Złotek et al. (2014) used different chemical elicitors (arachidonic, jasmonic, and abscisic acids) and reported levels of phenolic compounds ( $0.50 \mathrm{mg} \mathrm{GAE} / \mathrm{g} \mathrm{FW})$ similar to those in our control group ( $0.66 \mathrm{mg} \mathrm{GAE} / \mathrm{g}$ fresh weight $(\mathrm{FW}))$. However, their treatment with jasmonic acid treatment at $1 \mu \mathrm{M}$ increased phenolics (1.40 mg GAE/g FW) to values higher than those yielded by our treatment with the highest Harpin dose (1.12 mg GAE/g FW). Also, samples treated with jasmonic acid at $100 \mu \mathrm{M}$ showed similar results (1 mg GAE/g FW) as ours.

Accumulation of phenolic compounds has been related to a hypersensitive response prompted by genes involved in the synthesis of secondary metabolites such as phenolic compounds that may have antimicrobial activity (Sanzón \& Zavaleta, 2011). Phenylpropanoid metabolism has been reported to be involved in fruit-pathogen interactions (Ballester et al., 2006).

Our data indicate that using elicitors on green lettuce may be an effective approach to enhancing polyphenols. Moreover, this method is popular among consumers since genetically modifying vegetables as a strategy to enhance phenolic compounds is not generally accepted (Złotek et al., 2014).
No significant changes were observed in red lettuce variety treated with Harpin protein, compared to control, even though a slight decrease was observed at higher Harpin concentrations, reducing its phenolic content from $30.61 \pm 3.83$ in the control group to its lowest level of $24.87 \pm 1.68 \mathrm{mg} \mathrm{GAE} / \mathrm{g} \mathrm{DW}$ in the group treated with $45 \mathrm{mg} / \mathrm{L}$ of Harpin protein. Although the Harpin treatment was not effective to increases phenolic content in red lettuce, in all cases their content was higher compared to green lettuce samples. This pattern was previously reported by Liu et al. (2007) and Llorach et al. (2008) where red lettuce showed higher phenolic content compared to green lettuce. Some reports have shown that red lettuce varieties may present a slower metabolism than green ones. Moreno-Escamilla et al. (2017) described no changes for red Butterhead (Lactuca sativa var capitata) when elicitor application was shorter than 15 days before harvesting point. Nonetheless, green varieties showed best result with only 7 days before harvest and some changes were evident 3 days before harvest, in agreement with the results obtained in the present study.

\subsection{Effect of Harpin on individual phenolic compounds}

Figure 1 shows chromatograms of phenolic standards (A), green lettuce control samples (B), and green lettuce samples treated with the highest Harpin protein dose $(120 \mathrm{mg} / \mathrm{L})(\mathrm{C})$. Chlorogenic acid was the only phenolic compound identified in green lettuce samples after Harpin protein treatment. Control samples did not show a detectable amount of this compound. Levels of chlorogenic acid increased in a dose-dependent manner with Harpin protein treatment showing values of 623,634 , and $762 \mu \mathrm{g} / \mathrm{g}$ DW, for Harpin doses of 45, 60, and $120 \mathrm{mg} / \mathrm{L}$, respectively. This behavior agrees with data reported by Oh et al. (2009) who applied different physical stressors (heat shock, chilling, and high light intensity) on lettuce samples. All triggers showed an increase of chlorogenic acid; however, strong light intensity induced the highest chlorogenic acid content at $1.5 \mathrm{mg} / \mathrm{g} \mathrm{FW}$ (Oh et al., 2009). In another study, three elicitors (arachidonic, jasmonic, and abscisic acids) were applied to Butterhead lettuce, showing that chlorogenic acid contents increased in lettuce treated with arachidonic and jasmonic acids (9.28 and $4.94 \mu \mathrm{g} / \mathrm{g}$ FW, respectively vs. $2.67 \mu \mathrm{g} / \mathrm{g}$ FW in the control group). This behavior was explained due to the antifungal function of chlorogenic acid, as well as its role in disease reduction through the formation of defense barriers (especially lignin and suberin) (Złotek et al., 2014).

\subsection{Effect of Harpin application on antioxidant capacity}

Table 2 shows antioxidant capacity in samples of green and red lettuce varieties. Antioxidant capacity increased in green lettuce samples treated with $120 \mathrm{mg} / \mathrm{L}$ Harpin when compared against the control group. The DPPH method yielded values ranging from $45.69 \pm 3.41$ (120 mg/L Harpin) to $31.19 \pm 5.52 \mu \mathrm{mol} \mathrm{TE} / \mathrm{g}$ DW (control group). Such values suggest a $46.49 \%$ increase of antioxidant capacity in Harpin-treated samples. On the other hand, the FRAP method showed a more powerful response of antioxidant capacity to Harpin treatment. Samples treated with the highest dose showed values of $2.07 \pm 0.33 \mu \mathrm{mol}$ TE/g DW whereas antioxidant capacity in the control group was only $1.26 \pm 0.05 \mu \mathrm{mol}$ TE/g DW. The FRAP method showed that the $120 \mathrm{mg} / \mathrm{L}$ Harpin protein treatment increased its antioxidant 

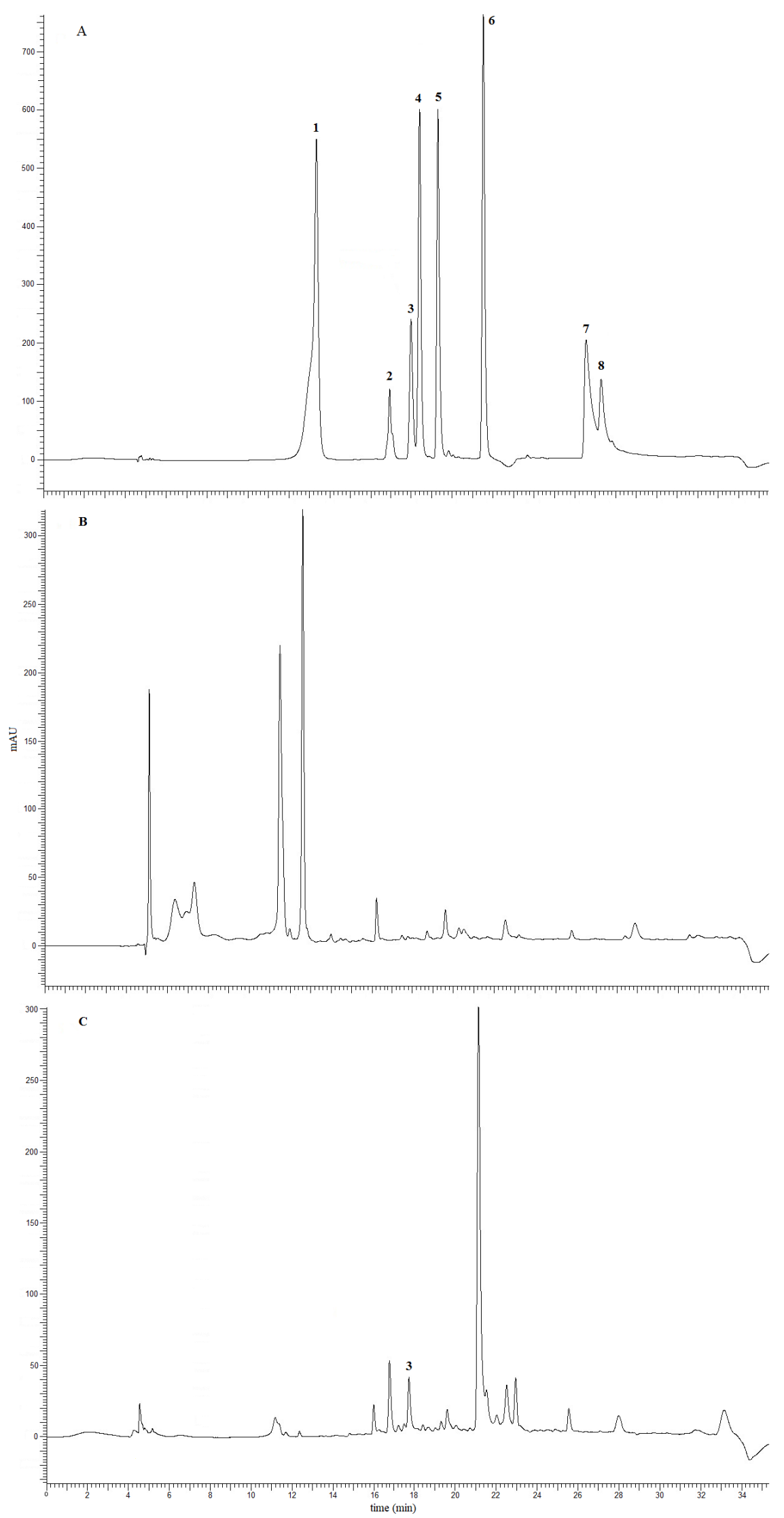

Figure 1. Chromatograms of phenolic standards (A), phenolic profile of green lettuce control (B), and green lettuce treated with Harpin protein $(120 \mathrm{mg} / \mathrm{mL})(\mathrm{C})$. Standards were as follows: 1 Gallic acid, 2 Catechin, 3 Chlorogenic acid, 4 Epicatechin, 5 Caffeic acid, 6 p-Coumaric acid, 7 Quercetin, 8 Luteolin. 
Table 2. Antioxidant capacity ( $\mu \mathrm{mol} \mathrm{TE} / \mathrm{g} \mathrm{DW})$ of control and Harpin-treated samples of green and red lettuce.

\begin{tabular}{|c|c|c|c|c|c|c|}
\hline \multirow{2}{*}{ Treatment } & \multicolumn{2}{|c|}{$\mathrm{DPPH}$} & \multicolumn{2}{|c|}{ ABTS } & \multicolumn{2}{|c|}{ FRAP } \\
\hline & Green & Red & Green & Red & Green & Red \\
\hline Control & $31.19 \pm 5.5^{\mathrm{a}}$ & $116.30 \pm 20.4^{\mathrm{a}}$ & $106.00 \pm 6.3^{\mathrm{a}}$ & $201.21 \pm 22.9^{\mathrm{a}}$ & $1.26 \pm 0.1^{\mathrm{a}}$ & $3.82 \pm 0.5^{\mathrm{a}}$ \\
\hline Harpin $45 \mathrm{mg} / \mathrm{L}$ & $37.73 \pm 7.2^{\mathrm{ab}}$ & $103.36 \pm 0.6^{\mathrm{a}}$ & $105.68 \pm 7.7^{\mathrm{a}}$ & $172.01 \pm 28.1^{\mathrm{a}}$ & $1.38 \pm 0.1^{\mathrm{a}}$ & $3.53 \pm 0.3^{\mathrm{a}}$ \\
\hline Harpin $60 \mathrm{mg} / \mathrm{L}$ & $40.86 \pm 1.2^{\mathrm{ab}}$ & $93.95 \pm 13.2^{\mathrm{a}}$ & $99.88 \pm 10.3^{\mathrm{a}}$ & $146.42 \pm 40.6^{\mathrm{a}}$ & $1.42 \pm 0.0^{\mathrm{a}}$ & $3.47 \pm 0.2^{\mathrm{a}}$ \\
\hline Harpin $120 \mathrm{mg} / \mathrm{L}$ & $45.69 \pm 3.4^{\mathrm{b}}$ & $104.06 \pm 8.2^{\mathrm{a}}$ & $105.25 \pm 7.9^{\mathrm{a}}$ & $149.50 \pm 27.7^{\mathrm{a}}$ & $2.07 \pm 0.3^{\mathrm{b}}$ & $3.50 \pm 0.1^{\mathrm{a}}$ \\
\hline
\end{tabular}

Data are average \pm SD of 3 analyses. Different letters in the same column indicate a significant difference between groups (ANOVA and Tukey's test, p $<0.05$ ). DPPH: 2,2-diphenyl-1picrylhydrazyl radical, ABTS: 2,2'-azino-bis (3-ethybenzothiazoline-6-sulphonic acid) radical, FRAP. Ferric Reducing Antioxidant Power.

capacity by $67.3 \%$. High correlations between phenolic content and antioxidant capacity (DPPH and FRAP) were observed for green lettuce, indicating that, in green lettuce samples, phenolic compounds may be the most important phytochemicals responsible of antioxidant capacity. However, the ABTS method showed no effect of Harpin treatment on antioxidant capacity. This behavior was also reported by Viacava et al. (2014), who reported a difference in antioxidant capacity between outer and inner leaves with DPPH and TEAC methods, but no differences when the oxygen radical absorbance capacity method was used. Antioxidant capacity values can vary between methods. Viacava et al. (2014) reported values of antioxidant capacity evaluated by DPPH ranging from 11.82 to $5.68 \mu \mathrm{mol} \mathrm{TE} / \mathrm{g}$ DW for outer and inner leaves respectively. Both values were lower than those found in our study despite our samples being a mixture of outer and inner lettuce leaves. One of the few studies on lettuces to use Harpin protein as elicitor is the one by Fonseca et al. (2009), where they reported an antioxidant increase of about $40 \%$ by the DPPH method. These results are similar to the ones reported here $(46.5 \%)$. These same authors found values of antioxidant capacity of about 22 in the control group to $30 \mu \mathrm{mol}$ TE/g DW for samples treated with 60 and $90 \mathrm{mg} / \mathrm{L}$ of Harpin protein. These values also agree with those found in our assay: 31 in the control group and almost $46 \mu \mathrm{mol} \mathrm{TE} / \mathrm{g}$ DW in the highest Harpin dose.

Another study where six lettuce cultivars were treated with different day and night temperatures showed values of antioxidant capacity that fluctuated between 5.87 for warm temperatures to $60.18 \mu \mathrm{mol} \mathrm{TE} / \mathrm{g}$ DW for colder temperatures (Boo et al., 2011). Only the lettuces treated with the two coldest temperatures showed higher antioxidant capacity (60.18 and 59, $87 \mu \mathrm{mol} \mathrm{TE} / \mathrm{g}$ DW) than our lettuces treated with Harpin protein. For the red variety lettuce, no significant effect was observed at any Harpin concentration by any of the used antioxidant capacity methods. This is consistent with the phenolic content results, where no increase was observed after Harpin treatment at any of the tested concentrations. In agreement with phenolic content, the antioxidant capacity of red samples were higher than those of green lettuce. This lack of increment on phenolic content and antioxidant capacity may be explained considering that red lettuce varieties may show a slower secondary metabolism than green ones, as stated before.

\section{Conclusions}

Elicitation may be an effective approach to enhancing phenolic content and therefore antioxidant capacity in green Butterhead lettuce. However, the effectiveness of the treatment strongly depends on lettuce variety. Still, Harpin protein elicitation may be valuable for lettuces with a low basal content of antioxidants. On the other hand, Chlorogenic acid was the phenolic compound identified that increased in response to Harpin treatment.

\section{References}

Akbudak, N., Tezcan, H., Akbudak, B., \& Seniz, V. (2006). The effect of harpin protein on plant growth parameters, leaf chlorophyll, leaf colour and percentage rotten fruit of pepper plants inoculated with Botrytis cinerea. Scientia Horticulturae, 109(2), 107-112. http:// dx.doi.org/10.1016/j.scienta.2006.03.008.

Alvarez-Parrilla, E., Rosa, L. A., Amarowicz, R., \& Shahidi, F. (2011). Antioxidant activity of fresh and processed jalapeño and serrano peppers. Journal of Agricultural and Food Chemistry, 59(1), 163-173. http://dx.doi.org/10.1021/jf103434u. PMid:21126003.

Alvarez-Parrilla, E., Rosa, L. A., Legarreta, P., Saenz, L., RodrigoGarcía, J., \& González-Aguilar, G. A. (2010). Daily consumption of apple, pear and orange juice differently affects plasma lipids and antioxidant capacity of smoking and non-smoking adults. International Journal of Food Sciences and Nutrition, 61(4), 369-380. http://dx.doi.org/10.3109/09637480903514041. PMid:20109132.

Ballester, A. R., Lafuente, M. T., \& González-Candelas, L. (2006). Spatial study of antioxidant enzymes, peroxidase and phenylalanine ammonia-lyase in the citrus fruit-Penicillium digitatum interaction. Postharvest Biology and Technology, 39(2), 115-124. http://dx.doi. org/10.1016/j.postharvbio.2005.10.002.

Boo, H. O., Heo, B. G., Gorinstein, S., \& Chon, S. U. (2011). Positive effects of temperature and growth conditions on enzymatic and antioxidant status in lettuce plants. Plant Science, 181(4), 479-484. http://dx.doi.org/10.1016/j.plantsci.2011.07.013. PMid:21889055.

Fonseca, J. M., Kim, H. J., Kline, W. L., Wyenandt, C. A., Hoque, M., \& Ajwa, H. (2009). Effect of preharvest application of a secondgeneration Harpin protein on microbial quality, antioxidants, and shelf life of fresh-cut-lettuce. Journal of the American Society for Horticultural Science, 134, 141-147.

Liu, X., Ardo, S., Bunning, M., Parry, J., Zhou, K., Stushnoff, C., Stoniker, F., Yu, L., \& Kendall, P. (2007). Total phenolic content and DPPH radical scavenging activity of lettuce (Lactuca sativa L.) grown in Colorado. Lebensmittel-Wissenschaft + Technologie, 40(3), 552-557. http://dx.doi.org/10.1016/j.lwt.2005.09.007.

Llorach, R., Martínez-Sánchez, A., Tomas-Barberan, F. A., Gil, M. I., \& Ferreres, F. (2008). Characterization of polyphenols and antioxidant properties of five lettuce varieties and escarole. Food Chemistry, 108(3), 1028-1038. http://dx.doi.org/10.1016/j.foodchem.2007.11.032. PMid:26065768.

López, A., Javier, G.-A., Fenoll, J., Hellín, P., \& Flores, P. (2014). Chemical composition and antioxidant capacity of lettuce: Comparative study of regular-sized (Romaine) and baby-sized (Little Gem and Mini 
Romaine) types. Journal of Food Composition and Analysis, 33(1), 39-48. http://dx.doi.org/10.1016/j.jfca.2013.10.001.

Martínez-Ballesta, M. C., López-Pérez, L., Hernández, M., LópezBerenguer, C., Fernández-García, N., \& Carvajal, M. (2008). Agricultural practices for enhanced human health. Phytochemistry Reviews, 7(2), 251-260. http://dx.doi.org/10.1007/s11101-007-9071-3.

Moreno-Escamilla, J. O., Alvarez-Parrilla, E., de la Rosa, L. A., NúñezGastélum, J. A., González-Aguilar, G. A., \& Rodrigo-García, J. (2017). Effect of different elicitors and preharvest dayapplication on the content of phytochemicals and antioxidant activity of Butterhead lettuce (Lactuca sativa var. capitata) produced under hydroponic conditions. Journal of Agricultural and Food Chemistry, 65(26), 52445254. http://dx.doi.org/10.1021/acs.jafc.7b01702. PMid:28613869.

Oh, M. M., Carey, E. E., \& Rajashekar, C. B. (2009). Environmental stresses induce health-promoting phytochemicals in lettuce. Plant Physiology and Biochemistry, 47(7), 578-583. http://dx.doi. org/10.1016/j.plaphy.2009.02.008. PMid:19297184.
Rosa, L. A., Alvarez-Parrilla, E., \& Shahidi, F. (2011). Phenolics compounds and antioxidant activity of kernels and shells of Mexican pecan (Carya illinoinensis). Journal of Agricultural and Food Chemistry, 59(1), 152-162. http://dx.doi.org/10.1021/ jf1034306. PMid:21138247.

Sanzón, G. D., \& Zavaleta, M. E. (2011). Respuesta de hipersensibilidad, una muerte celular programada para defenderse del ataque por fitopatógenos. Revista Mexicana de Fitopatología, 29, 154-164.

Viacava, G. E., Gonzalez-Aguilar, G. A., \& Roura, S. I. (2014). Determination of phytochemicals and antioxidant activity in butterhead lettuce related to leaf age and position. Journal of Food Biochemistry, 38(3), 352-362. http://dx.doi.org/10.1111/jfbc. 12060.

Złotek, U., Swieca, M., \& Jakubczyk, A. (2014). Effect of abiotic elicitation on main health-promoting compounds, antioxidant activity and commercial quality of butter lettuce. Food Chemistry, 148, 253-260. http://dx.doi.org/10.1016/j.foodchem.2013.10.031. PMid:24262554. 